\author{
Mariia Minchenko, \\ Ph.D., Associate Professor, Sumy State University, Ukraine \\ iD ORCID ID, 0000-0002-6768-1627 \\ email:m.minchenko@uabs.sumdu.edu.ua \\ Kateryna Demchuk, \\ University of Applied Sciences of Hamburg, Germany \\ D ORCID ID, 0000-0001-9556-1625 \\ email: katerynademchuk@icloud.com \\ Correspondence author: m.minchenko@uabs.sumdu.edu.ua
}

\title{
PANDEMIC CONSEQUENCES AND CRISIS RECOVERY SCENARIOS
}

Abstract. The global economy develops in completely new and unpredictable conditions due to the COVID-19 pandemic spread. The current COVID-19 crisis has changed the supply and demand ratio. Economic recovery requires the right macroeconomic policy to support national economies, maintain economic and financial relationships between workers and enterprises, creditors and borrowers, suppliers, and end consumers. Therefore, there is a challenge to minimize the influence of the long-term COVID-19 crisis to avoid irreparable damage to people and companies due to job losses and mass bankruptcies. This study aims to analyze the COVID-19 consequences and scenarios of economic recovery after the pandemic crisis. The study's relevance is that the global economy needs significant behavioral, structural, and institutional changes to stabilize the system and form the basis for further development. The findings showed that the COVID-19 pandemic has become a trigger of devastating large-scale world economic imbalances. The authors noted that one of the combating methods against the pandemic spread was quarantine measures. However, the massive population isolation, limiting its mobility and economic activity, has created an extraordinary socio-economic situation. The authors conclude that pandemic significantly increased the demand for food delivery services since people preferred (or were forced) to stay at home. At the same time, people were apprehensive about coronavirus transmission through couriers. The prolonged quarantine has changed consumer behavior. Notably, the demand for such goods as cars and clothing decreased while increased for household products. Most developed and many developing countries have sacrificed their economies to defend the population. The authors concluded that the social changes caused by quarantine restrictions have divided the world into current and «post-COVID» and affect all global economic fields. The obtained results indicated the need to find new possibilities to simplify production and manage remote work. The study findings emphasize the need to find new possibilities to simplify production. Moreover, it is essential to establish links between manufacturers and economic systems under remote work.

Keywords: digitalization, COVID-19, crisis, crisis recovery scenarios, economic development, pandemic.

Introduction. Most analysts, financiers, and economic experts predicted the financial crisis even before the coronavirus spread worldwide. Thus, the global pandemic has made significant adjustments to world economic development. It stands to note that on 30 January 2020, the WHO declared the COVID19 disease a health emergency. There were more than 9000 infected people in 18 countries. In turn, as of the end of March 2021, the number of patients with laboratory-confirmed COVID-19 was near125 million, while approximately 71 million were cured.

On the other hand, the pandemic caused the world economic decline by $1.5 \%$. Based on Bloomberg forecast, the world economy would lose 5 trillion USD in 2020-2021. Besides, many publishers such as CNN, The Guardian, New York Times, Bloomberg believed that the pandemic would result in a global economic recession. However, they predicted different depths and duration of global economic recession due to the indefinite pandemic period. Notably, most countries that implemented quarantine curtailed the

Cite as: Minchenko, M., \& Demchuk, K. (2021). Pandemic Consequences and Crisis Recovery Scenarios. Health Economics and Management Review, 1, 67-75. http://doi.org/10.21272/hem.2021.1-07

67 
investment projects and social and financial support programs. Following the paper (Andrews and Dash, 2009), the recovery would depend on the coronavirus resistance and its spread worldwide.

It is worth indicating that the global crisis in 2009 was not as devastating as the COVID-19. Thus, the world's leading countries have spent less than 1 trillion USD to combat its effects (at current exchange rates). In turn, in the USA, GDP fell by $1.2 \%$ in the quarter, while in the EU - by $3.5 \%$. The extrapolation results showed that the annual decline rate of the European economy in the first quarter exceeded 13\%, while in the USA - by $4.8 \%$.

It stands to mention that the Morgan Stanley economists forecast, the developed markets could recover status quo in the third quarter of 2021. On the other hand, Deutsche Bank AG estimates that the USA and the EU economies lose 1 trillion USD by the end of 2021 due to pandemic influence. In turn, the World Trade Organization (WTO) reports that the pandemic will provoke a world trade collapse which would be worse than during World War II. Therefore, the governments would have to cooperate and coordinate their efforts. Besides, the Bank for International Settlements (BIS) warns that disparate efforts could provoke the second wave of the pandemic, after which GDP could fall by $12 \%$ compared to the end of 2020.

Therefore, the mentioned above indicated that the quarantine and restrictive measures against COVID-19 significantly affected the world economy is. Thus, the world's developed countries have enforced quarantine and mask regimes, closed educational institutions, and different enterprises. Besides, over a hundred countries closed their borders for a whole year. Therefore, the quarantine restrictions on the movement led to the cancellation or postponement of many local and global events such as the Tokyo 2020 Olympic Games, the World Cup in soccer, Italian Serie A, Premier League, fashion parade, etc. (Burkert and Loeb, 2020).

Experts from the Institute of International Finance (IIF) stated that in 2019 the amount of global debt increased by more than 10 trillion USD and gained a record level ( 255 trillion USD). It stands to note that the IIF experts included the debts of governments, banks, non-financial corporations, and households into the total global debt. Besides, the researchers indicated that the total global debt caused by COVID-19 exceeded the early financial crisis in 2008 by 40 percent (87 trillion USD).

On the other hand, quarantine measures resulted in the encase or partial closure of enterprises. As a result, 2.7 billion people (81\% of the world's workforce) lost jobs. Herewith, the most affected economic industries were the hotel business, administrative services, industrial production, and wholesale and retail trade. According to the International Labor Organization, above 25 million people could lose their jobs due to the pandemic.

Notably, the financial crisis in 2008 didn't destroy global technological and logistical chains. Besides, there was no stoppage in production and border closure. The current global debt exceeds the global income by three times.

Nowadays, investors pay great attention to stock quotations of transport companies since a fall in the raw materials transportation market may determine the deeper problems in the stock market. It is worth mentioning some companies suffered less, including third-party logistics providers. For example, the share of stocks of Landstar System and Expeditors International of Washington coordinating shipping orders dominate during the current stock market crisis.

Literature Review. Studies of changes in the socio-economic sphere are widely represented in the scientific community. Many works of scientists address this issue. It was investigated by Alfano and Ercolano (2020), Pfeiffer and roeger (2020), Tovmasyan and Minasyan (2020), Rahmanov et al. (2020), Vasilyeva et al. (2020), Us et al. (2020).

Scenario analysis requires experts to consider the risk chain. Thus, the unpredictable coronavirus spread provokes risk intensification for the global and national economies. This study provides the 
classification of mentioned above risks which could threaten the economic functioning if the pandemic situation is worse.

Therefore, the first group is the pandemic continuation risk. It means that governments hardly control the situation after the weakening of the quarantine measures. Thus, the national and global economies make significant long-term losses.

The second group is the social instability risks. That applies to social unrest associated with rising unemployment, declining social standards, and overmuch anti-epidemic implemented by the national government. The mentioned above complicates the effective quarantine measures implementation.

It stands to identify the risk group of aggravation in international trade relations. Given the national economic difficulties, some countries are unable to expand imports of goods. Thus, it results in import tariff growth. Besides, this risk is characterized by several features developed both during the pandemic and before.

Undoubtedly, the distance studying and working reduced the frequency of business trips and the study period. Face-to-face meetings lost their relevance while the number of online business meetings significantly increased. In this case, the aviation, hotel, and tourism industries were the first to suffer. Besides, many organizations officially announced the transition to $100 \%$ remote work. Moreover, they have no intention to return to the old model after pandemic completion.

It could be assumed that consumers will be cautious much. Thus, they would be more thoughtful in weighing the need for purchasing or using certain goods. In turn, it will affect consumption expenditures and, consequently, retail sales. Excepting total protectionism, supply will exceed demand. Thus, excess savings will lower inflation and interest rates. Herewith, low inflation and possible deflation will weaken the population's propensity to spend, preventing economic recovery. Crash in crude oil prices may push countries to new business matching provoking new oil wars (Yap, 2020).

It is fair to assume that lending standards will be tightened worldwide, as in mortgage loans after the failure of subprime lending. On the other hand, the treasury bonds will be attractive even with unchanged or possibly negative real returns due to deflation. The changes could also affect pension funds due to the transition to riskier investments for higher returns.

The findings demonstrate different forecasts for the world economy decline vary from $6 \%$ in 2022 to a growth of $0.7 \%$. However, on average, experts predict a prolonged downturn by $1.2 \%$. It is worth noting that currently, accurate forecasts are impossible due to the situation's uniqueness while fully operating economies came to their large-scale stop in a matter of weeks. However, despite the forecast complexity, it is possible to form four main scenarios for overcoming the pandemic crisis worldwide (Table 1).

Table 1. The crisis recovery scenarios

\begin{tabular}{|c|c|}
\hline Scenario & Main features \\
\hline $\begin{array}{l}\text { V-shaped: sharp decline } \\
\text { and growth }\end{array}$ & $\begin{array}{l}\text { Proponents of this scenario suggest that a sharp decline is followed by equally rapid } \\
\text { growth near the pre-crisis level. } \\
\text { Several economists suggested that governments' stimulus moves could provide } \\
\text { rapid economic recovery in autumn after a large-scale drop in the world GDP in } \\
\text { summer. } \\
\text { Starting a business and business activity resumption might deliver measurable } \\
\text { results in the Q3-Q4 } 2022 \text {. }\end{array}$ \\
\hline $\begin{array}{l}\text { U-shaped: decline, } \\
\text { stagnation and flashy } \\
\text { growth }\end{array}$ & $\begin{array}{l}\text { Under this scenario, recovery needs more than several quarters. Many surveyed } \\
\text { economic experts hold that the COVID-19 crisis is more similar to the financial crisis } \\
\text { in 2008-2009. } \\
\text { Withdrawal from quarantine would be smooth, affecting the economic recovery. } \\
\text { Notably, many industries (such as tourism) would recover more slowly. }\end{array}$ \\
\hline
\end{tabular}


Continued Table 1

W-shaped: recovery and This is the scenario of «double-decline». The reduced lockdown measures would the second crisis wave promote economic recovery while the crisis lasts. Quarantine would cause bankruptcy in different businesses, while unemployment will rise. The second pandemic wave is possible in the late summer caused by withdrawing quarantine measures.

L-shaped: slump In this scenario, no provision exists for rapid economic recovery or economic growth. This scenario might realize if the coronavirus pandemic is not overcome in the coming months. Thus, the lockdowns will hold worldwide. In turn, if they are canceled, there might be repeated COVID-19 outbreaks.

Despite that, the probability of the above mention negative development is unlikely.

That is evidenced by the Wuhan experience, as the first COVID-19 epicenter picked up to normal.

However, the L-shaped scenario is appropriate for some economies. The countries with hardly controlled economies and dependence on export are at high risk.

Sources: developed by the authors based on (Andrews and Dash, 2009; Yap, 2020; IASS, 2020; Baldwin and Weder di Mauro, 2020).

Most rating agencies and economists become more skeptical towards the V-shaped scenario of global economic recovery. Instead, they assume economic recovery as fluctuate thrusts. This scenario assumes a gradual decline and then recovery in a few thrusts facilitated by a gradual loosening of quarantine measures and a sharp uncontrolled return to severe restrictions. The situation will also be affected by declining demand, as the population is forced to save money. Therefore, this recovery scenario is one of the most likely.

By generalizing the experts' opinions and rating companies' reports, it is possible to predict that the pandemic will be overcome in most countries by vaccination. Therefore, most countries will return to normal by the end of the second quarter of 2022.

It stands to mention that life changes will not be profound and irreversible. In turn, the general recovery rate depends on industries recover unevenly. This development scenario is demonstrated by China, which has already survived several pandemic waves. Tourism, air travel, export-oriented industries, international manufacturing, traditional services, and entertainment will take much longer to recover. The odds are that global and national recovery schedules would most likely be V-shaped (sharp decline and equally sharp recovery) or U-shaped (the rise will be delayed because many companies have to restore production chains and re-hire employees).

In the case the situation is out of control, then scenario $L$ is possible. Herewith, the governments would not support enterprises and banks. Thus, many of them could go bankrupt or lose competitiveness, causing a debt crisis and a lack of liquidity. The business and bank collapse threaten the global financial system and production crises for 2-3 years. Under the $L$ scenario, China is ahead. Thus, declining the growth rate by 2 times in 2019, the country recovers by mid-2022. The USA loses more than $8 \%$ of GDP, while the EU - near 10\%. Based on the analysts' forecast, these countries could recover the level of 2019 at the end of 2023.

The other way round, toned-down and more likely predictions indicate that the fourth COVID-19 wave would complicate and delay economic recovery. The pandemic will continue. However, the global public vaccination will allow recovering the global economy saved its structure. Therefore, the global economy could recover a year earlier. Notably, developing countries, which underwent deep crises recently, could easier survive a new crisis. However, the COVID-19 pandemic will affect the economic and social fields and the international political situation despite the scenario type. 
Methodology and research methods. This study gives a forecast of GDP change depending on the global pandemic duration. Therefore, it is essential to use a dynamic factor model providing the most accurate short-term forecast, considering the factor dynamics and more high-frequency data. The mentioned above significantly increases the accuracy of estimating GDP changes for the quarter and improves the short-term forecast using the most up-to-date data. The forecast was conducted for Q3 2021Q2 2022, considering the restrictive measures during these quarters.

For empirical calculations, this study involved the data of the World Bank and the State Statistics Service. The forecast period is 2014-2020. The list of used indicators are as follows:

1. Real GDP Index (quarter and chain).

2. Index of Real Output (quarter and chain).

3. Index of Real Income (quarter and chain).

4. Consumer Price Index (monthly and chain).

5. Unemployment Rate (chain).

6. Output Index by Basic Economic Activities.

7. Manufacturing Index (chain).

8. Real Agricultural Production Volume Index (chain).

9. Index of Real Retail Trade Turnover.

10. Wage Index.

11. Producer Price Index in Industry

12. Average monthly effective credit rates.

13. Export Price Index (chain).

14. Import Price Index (chain).

In the study, the Multiple Linear Regression Model was used to estimate GDP. Besides, the authors applied the statistics online calculators' tools (Statistics Kingdom, 2020) and resources of XLSTAT by Addinsoft (2020). Figure 1 shows the forecast values in the chain GDP growth changes for different countries, considering the decline in economic indicators due to pandemic.

Results. The significant correlation between the factors confirms the dependence and strong relationship between GDP and the selected indicators (Table 2). The forecast is based on the assumption that each previous quarter is the period of pandemic continuation in the world.

Notably, the pandemic continuation will negatively affect the GDP change for all investigated countries. Table 2 shows the forecast data on the GDP percentage change for Q3 2021-Q2 2022.

Table 2. The forecast on the GDP change for 2021-2022, \%

\begin{tabular}{|c|c|c|c|c|c|}
\hline \multirow[t]{2}{*}{ Country } & \multicolumn{5}{|c|}{ Forecast quarters } \\
\hline & Q3 2021 & Q4 2021 & Q1 2022 & Q2 2022 & Q3 2022 \\
\hline Bolgaria & 10,6 & $-1,57$ & $-4,4$ & $-13,1$ & $-13,4$ \\
\hline Great Britain & 13,5 & $-2,5$ & $-5,4$ & $-7,8$ & $-11,1$ \\
\hline Italy & 3,19 & $-3,8$ & $-8,7$ & $-11,4$ & $-14,9$ \\
\hline Lithuania & 13,4 & $-3,7$ & $-8,8$ & $-13,6$ & $-17,1$ \\
\hline Germany & 4,3 & $-1,2$ & $-3,6$ & $-3,9$ & $-6,9$ \\
\hline Poland & 8,3 & $-8,8$ & $-9,9$ & $-10,9$ & $-14,9$ \\
\hline $\begin{array}{l}\text { Republic of } \\
\text { Moldova }\end{array}$ & 23,7 & $-3,8$ & $-11,4$ & $-16,1$ & $-21,1$ \\
\hline Ukraine & 1,4 & $-11,4$ & $-17,7$ & $-18,9$ & $-20,9$ \\
\hline France & 13,5 & $-8,7$ & $-13,5$ & $-11,4$ & $-20,1$ \\
\hline Switzerland & 17,5 & $-0,9$ & $-2,8$ & $-3,7$ & $-5,9$ \\
\hline
\end{tabular}

Sources: developed by the authors. 
Table 2 shows that the forecast GDP change values are positive in Q2 2021 due to the previous investing. In turn, the significant deterioration of the situation would be at the beginning of Q4 2021. Besides, the results show that the worst forecast in less economically stable countries, such as Moldova, Ukraine, and Lithuania, is because of the lack of reserves to support the social sphere and business. If the pandemic continues, France and Italy will also suffer more. Notably, these countries were the first in Europe to suffer the negative lockdown effects and severance of economic ties during this period.

Despite the negative forecasts, the world economy is a very adaptive system. Several positive directions show signs of recovery after the pandemic. Herewith, it stands to mention the dominating tendencies in the post-pandemic world society are as follows:

1. Changing in the relationship between employees and employers:

- $\quad$ up to $80 \%$ of employees could lose jobs due to business processes optimization, digitalization, and e-document management;

- $\quad$ the employees would be under no obligation to work at the office on a full-time basis. The analysts stated that two days a week could be enough for office work, while the rest time they could successfully work remotely. Notably, based on the findings, employees can concentrate on work for 2.5-3 hours at the office. The rest of the time is spent on social networks and communication with colleagues. In the case of remote work, they work even more than 8 hours a day since there is only one significant indicator of work - efficiency (number of successfully solved professional tasks per unit time);

- $\quad$ the office areas could be reduced by 2-3 times. Thus, the owners might cut corners on furniture, office equipment, stationery, or other additional services. Besides, it can also be located not in the city center. However, it is necessary to provide the location with convenient transport communication and access roads.

2. Transition to a more digitalized economic infrastructure increased digital developments in document management, training, logistics, etc.

Therefore, based on the mentioned above, it is possible to identify the mainstream shaping postpandemic economic development (Table 3).

Table 3. Main tendencies shaping post-pandemic economic development

\begin{tabular}{ll}
\hline \multicolumn{1}{c}{ Tendency } & \multicolumn{1}{c}{ Major features } \\
\hline New digital technologies & - artificial inteligence \\
& - telemedicine \\
& - big data \\
& - messenger technology \\
& - registry allocation (blockchain) \\
& - augmented and virtual reality \\
& - online marketing \\
& - digitalization of open databases \\
\hline Digital transformation of & - Internet-banking expansion \\
markets & - transformation of transport market due to appearing online services of delivery \\
& services and passenger transportation \\
& - transition to marketplaces and gradual outlets constraint \\
& - e-document flow \\
& - localization large technological enterprises exclusionary by small engineering \\
& centers equipped with 3D technologies \\
\hline
\end{tabular}


Continued Table 3

\begin{tabular}{|c|c|}
\hline $\begin{array}{l}\text { Digital transformation of } \\
\text { organization and } \\
\text { management functions }\end{array}$ & $\begin{array}{l}\text { - automated big data management } \\
\text { - back-office transformation } \\
\text { - implementing infobots and chatbots } \\
\text { - practicing case management } \\
\text { - developing efficient management structures } \\
\text { - using blockchain technology maintaining e-document flow } \\
\text { - cybersecurity } \\
\text { - transiting most office staff to remote work } \\
\text { - providing real-time decision support systems }\end{array}$ \\
\hline $\begin{array}{l}\text { Digital transformation of } \\
\text { production processes }\end{array}$ & $\begin{array}{l}\text { - cyber-physical systems (integrating computing } \\
\text { - resources in physical processes) } \\
\text { - 3D-technologies (printing) or «additive manufacturing» (layered building and } \\
\text { synthesizing the object using computer 3D-technologies) } \\
\text { - robotics (automation development with industrial robots) } \\
\text { - open production technologies (physical objects are created based on the } \\
\text { principle of openness, interaction, and distribution, while the model - open } \\
\text { design and open source) } \\
\text { - applying engineering software (digital design and modeling) } \\
\text { - online consumption technologies (mass adoption of intelligent (quantum) } \\
\text { sensors) }\end{array}$ \\
\hline $\begin{array}{l}\text { Digital transformation in } \\
\text { consumption }\end{array}$ & $\begin{array}{l}\text { - e-commerce (extends convenient payment method without banks and } \\
\text { traditional payment systems such as electronic money and cryptocurrency) } \\
\text { - Internet banking (provides a set of programs and tools to control and use } \\
\text { accounts and deposits via the Internet fully) } \\
\text { - direct services (smart contract is an electronic protocol written using computer } \\
\text { code to transfer information and ensure contractual compliance by both parties. } \\
\text { Besides, they provide secure direct exchange money, shares, property, and } \\
\text { other assets without intermediaries) }\end{array}$ \\
\hline $\begin{array}{l}\text { Digital transformation } \\
\text { impact on employment }\end{array}$ & $\begin{array}{l}\text { - employment growth in development and supporting information technology } \\
\text { - professions transformation and stepping up the requirements for computer } \\
\text { literacy } \\
\text { - education system transformation } \\
\text { - retraining and advanced training } \\
\text { - competition rise in the labor market and stepping up the requirements for } \\
\text { - incressional knowledge and soft skills of employees } \\
\text { - labor market flexibility and employment instability } \\
\text { - remote work as a new employment form } \\
\text { - self-employment growth } \\
\text { - strengthening migration processes } \\
\text { - old professions disappearing and the emergence of new ones }\end{array}$ \\
\hline $\begin{array}{l}\text { General tendencies in } \\
\text { digital transformation }\end{array}$ & $\begin{array}{l}\text { - high-tech jobs growth } \\
\text { - remote work } 5 \text { days a week would increase the leisure activities demand } \\
\text { - work performance transformation } \\
\text { - the rise in the efficiency of production } \\
\text { - logistics services development (products delivery via the Internet) } \\
\text { - reducing the production cost for goods and services }\end{array}$ \\
\hline
\end{tabular}

Sources: developed by the authors. 
Table 3 presents the tendencies used to solve social problems, such as reducing unemployment and increasing incomes. Besides, they provide the opportunities to maximize profit, maintain financial stability, and contribute to general company efficiency. Undoubtedly, the pandemic influences economic functioning. Despite that, it is a significant search gate to enhance business activity.

Conclusions. The COVID-19 pandemic is one of the most unpredictable and destructive factors for the economy. The historical evolution passed through different epidemics and pandemics, which threatened global economic development. Notably, mass epidemics caused human losses, while they had a destructive impact on the economy. The systematization of scientific background showed that the current crisis is the most non-typical. It has significant negative economic consequences. Besides, the comparison with previous crises indicated that the COVID-19 pandemic completely changed conditions for supply and demand functioning. Thus, the disastrous tendencies in the global economy became visible. In turn, most governments took measures to combat the pandemic spread through mainstreaming quarantine, imposed people isolation, limited their mobility and economic activity. Therefore, that created an extraordinary social and economic situation. The pandemic caused the enterprises closure in the most COVID-injured countries. Besides, there was spiraled demand for everyday products, speculation in the market of particular goods such as anti-viral medication, facemasks, antiseptics, etc.

Moreover, the pandemic significantly increased the demand for food delivery services since people preferred (or were forced) to stay at home. At the same time, people were apprehensive about coronavirus transmission through couriers. Therefore, the contact-free delivery of food and other goods was demanded. The prolonged quarantine has changed consumer behavior. Notably, the demand for such goods as cars and clothing decreased while increased for household products.

The study indicated that the global pandemic significantly influenced the supply, especially foreign travel, production, and investment. Besides, the pandemic crisis provided losing jobs. It stands to indicate that the crisis duration determines its consequences. Thus, if the crisis is solved by the end of 2021, there would be minimum production losses during the global economic recovery. In turn, the forecast for several EU countries shows that GDP would fall from $3.6 \%$ to $17.7 \%$ if quarantine measures continue until the end of the year. On the other hand, if the pandemic continues until 2022, the economic downturn would deepen to $21 \%$.

The study findings emphasize the need to find new possibilities to simplify production. Moreover, it is essential to establish links between manufacturers and economic systems under remote work.

Author Contributions: conceptualization, M. M. and K. D.; methodology, M. M. and K. D.; validation, M. M.; formal analysis, K. D.; investigation, M. M. and K. D.; data curation, M. M.; writing-original draft preparation, M. M.; visualization, M. M. and K. D.; supervision, M. M.; project administration, M. M.

Funding: This research received no external funding.

\section{References}

Alfano, V., \& Ercolano, S. (2020). The efficacy of lockdown against COVID-19: a cross-country panel analysis. Applied health economics and health policy, 18, 509-517. [Google Scholar] [CrossRef]

Andrews, E. L., \& Dash, E. (2009). US Expands Plan to Buy Banks' Troubled Assets. New York Times. Retrieved from [Link] Baldwin, R., \& Di Mauro, B. W. (2020). Economics in the time of COVID-19: A new eBook. VOX CEPR Policy Portal. Google Scholarl

Burkert, A., \& Loeb, A. (2020). Flattening the COVID-19 Curves. Scientific American Blog Network. Retrieved from [Link]

Harvard University. (2020). Coronavirus (COVID-19). Retrieved from [Link]

Institute for Advanced Sustainability Studies e.V. (2020). How is COVID-19 affecting the global economic order? Scenarios for the global monetary system. ScienceDaily. Retrieved from [Link]

Lyulyov, O., Us, Y., Pimonenko, T., Kwilinski, A., Vasylieva, T., Dalevska, N., ... \& Boiko, V. (2020). The Link Between Economic Growth and Tourism: Covid-19 Impact. Proceedings of the 36th International Business Information Management Association (IBIMA), 8070-8086. [Google Scholar] 
Pfeiffer, P., \& Roeger, W. (2020). The COVID19-Pandemic in the EU: Macroeconomic Transmission and Economic Policy Response (No. 127). Directorate General Economic and Financial Affairs (DG ECFIN), European Commission. [Google Scholar]

Rahmanov, F., Aliyeva, R., Rosokhata, A., \& Letunovska, N. (2020). Tourism management in Azerbaijan under sustainable development: impact of COVID-19. Marketing and Management of Innovations, 3, 196-207. [Google Scholar] [CrossRef]

Statistics Kingdom. (2020). Statistics online. Retrieved from [Link]

Tovmasyan, G., \& Minasyan, D. (2020). The Impact of Motivation on Work Efficiency for Both Employers and Employees also During COVID-19 Pandemic: Case Study from Armenia. Business Ethics and Leadership, 4(3), 25-35. [Google Scholar] [CrossRef]

Us, Ya., Pimonenko, T., Tambovceva, T., \& Segers, J. P. (2020). Green transformations in the healthcare system: the covid-19 impact. Health Economics and Management Review, 1(1), 48-59. [Google Scholar] [CrossRef]

Vasilyeva T. A., Lyeonov S. V., \& Letunovska N. Y. (2020). The economic impact of COVID-19: forecasting for Ukrainian regions. Socio-Economic Challenges: Proceedings of the International Scientific and Practical Conference, Sumy, November 3-4, 2020. Sumy: Sumy State University. P. 18-22. Retrieved from [Link]

XLSTAT by Addinsoft. (2020). Retrieved from [Link] $\underline{[L i n k]}$

Yap, C. W. (2020). China's factories struggle to resume operations after virus shutdown. Wall Street Journal. Retrieved from

Марія Мінченко, Ph.D, доцент, Сумський державний університет (Україна);

Катерина Демчук, Університет прикладних наук Гамбурга (Німеччина)

Наслідки та сценарії виходу країн із кризи, спровокованої пандемією

У статті проаналізовано сценарії відновлення світової економічної системи під впливом пандемії COVID-19. Поширення пандемії COVID-19 змусило економічні системи діяти в абсолютно нових та непередбачуваних умовах. Поточна криза спровокувала значні негативні економічні наслідки, оскільки відбулися істотні зміни в умовах функціонування попиту пропозиції. Актуальність досліджуваного питання полягає у необхідності аналізу поведінкових, структурних та інституційних змін для стабілізації та подальшого розвитку економічної системи. Метою статті $€$ аналіз наслідків та сценаріїв виходу із кризи, спровокованої пандемією. Отримані результати вказують на необхідність ухвалення макроекономічних політичних рішень для підтримки функціонування економіки країн під час пандемії. Для відновлення економічної активності важливо зберегти мережу економічних і фінансових відносин між працівниками та підприємствами, кредиторами та позичальниками, постачальниками та кінцевими користувачами. Автори відмітили, що пандемія COVID-19 стала тригером масштабних руйнівних дисбалансів. Таким чином, завдання полягає в мінімізації негативного впливу пандемії COVID-19 на суспільство та бізнес через втрату робочих місць та масових банкрутств в країнах. Однак упроваджені заходи боротьби проти пандемії у вигляді карантину та примусової ізоляції населення обмежили його мобільність та економічну активність. Як наслідок, виникла безпрецедентна соціально-економічна ситуація, де захист та збереження здоров'я населення стали пріоритетними для більшості розвинених країн та країн, що розвиваються. Отримані результати засвідчили, що пандемія COVID-19, разом з іншими неслушними подіями в економічній, соціальній та політичній сферах, сприяють цифровій трансформації суспільства та всіх сфер світової економіки. У роботі автори наголосили на необхідності спрощення виробництва та налагодження зв'язків між виробниками та економічними системами в режимі віддаленого доступу.

Ключові слова: диджиталізація, криза, пандемія, сценарії виходу з кризи, світова економіка, COVID-19. 